\title{
PENGARUH KONSENTRASI GLISEROL DAN SORBITOL TERHADAP KARAKTERISTIK DAYA SERAP AIR EDIBLE FILM DARI PEKTIN KULIT PISANG
}

\author{
Nisya Qonita Zahra ${ }^{1}$, Royfa Fenandita Finadzir ${ }^{1}$, Fitria Yulistiani ${ }^{1, *}$ \\ ${ }^{1}$ Jurusan Teknik Kimia, Politeknik Negeri Bandung, Ciwaruga, Bandung Barat, Indonesia \\ "E-mail: fitria.yulistiani@ polban.ac.id
}

\begin{abstract}
ABSTRAK
Penggunaan edible film menghasilkan limbah dan polusi yang lebih sedikit, namun karakteristiknya masih belum mendekati sifat kemasan sintetis. Salah satu karakteristik yang perlu diperbaiki adalah daya serap air/WVTR (Water Vapor Transmission Rate). Pada penelitian ini dilakukan studi literatur mengenai pengaruh jenis dan konsentrasi pemlastis (gliserol dan sorbitol) terhadap karakteristik WVTR edible film dari pektin kulit pisang. Literatur yang akan dikaji dalam penelitian ini dibatasi pada hasil penelitian terkait pembuatan edible film berbasis pektin kulit pisang serta menggunakan pemlastis gliserol dan sorbitol. Pada produk edible film yang dibuat menggunakan pemlastis dengan konsentrasi $10 \%$, pemlastis sorbitol menghasilkan WVTR yang lebih rendah $\left(3,66\right.$ g. $\left.\mathrm{H}_{2} \mathrm{O} / \mathrm{jam} . \mathrm{m}^{2}\right)$ dibandingkan dengan pemlastis gliserol $\left(3,93 \mathrm{~g} . \mathrm{H}_{2} \mathrm{O} / \mathrm{jam} . \mathrm{m}^{2}\right)$. Dari kedua jenis pemlastis tersebut, konsentrasi yang memberikan nilai WVTR terendah $(3,66$ - 4,66 g. $\mathrm{H}_{2} \mathrm{O} / \mathrm{jam} . \mathrm{m}^{2}$ ) ada pada rentang $5-15 \%$. Dari seluruh hasil penelitian yang dikaji, karakteristik WVTR produk edible film sudah memenuhi Japanese Industrial Standard (JIS Z 1707, 1975).
\end{abstract}

Kata kunci: Edible film, pemlastis, daya serap air, pektin kulit pisang

\begin{abstract}
The use of edible films results in less waste and pollution, but their properties are still not close to those of synthetic packaging. One of its properties that need to be improved is its water vapor transmission rate (WVTR). In this study, a literature study was carried out regarding the effect of plasticizers (glycerol and sorbitol) on WVTR of edible film from banana peel pectin. The literature being studied in this study is limited to the research related to edible film production based on banana peel pectin and using glycerol and sorbitol plasticizers. In the edible film which is made using a plasticizer with concentration $10 \%$, sorbitol plasticizer produces the edible film with lower WVTR (3.66 g. $\left.\mathrm{H}_{2} \mathrm{O} / \mathrm{hr} \mathrm{m}^{2}\right)$ compared to glycerol plasticizers $\left(3.93 \mathrm{~g} . \mathrm{H}_{2} \mathrm{O} / \mathrm{hr} \cdot \mathrm{m}^{2}\right)$. Of the two types of plasticizers, the concentrations that give the lowest WVTR values $\left(3.66-4.66 \mathrm{~g} . \mathrm{H}_{2} \mathrm{O} / \mathrm{hr}^{2} \mathrm{~m}^{2}\right)$ are in the range of 5-15\%. From all the research results reviewed, the WVTR characteristics of edible film products have met the Japanese Industrial Standard (JIS Z 1707, 1975).
\end{abstract}

Keywords: Edible film, plasticizer, water vapor transmission rate, banana peel pectin

\section{PENDAHULUAN}

Pengemasan memiliki peran yang penting dalam industri proses, terutama industri pangan, yaitu untuk menjaga kualitas produk dan memperpanjang masa simpan produk. Kemasan pangan yang banyak digunakan oleh masyarakat adalah plastik, namun penggunaannya menjadi masalah lingkungan karena sifat plastik yang tidak mudah terurai. Oleh karena itu, banyak penelitian yang dilakukan untuk mencari bahan kemasan pangan yang ramah lingkungan, salah satunya adalah edible film.

Penggunaan edible film menghasilkan limbah dan polusi yang lebih sedikit, namun karakteristiknya masih belum mendekati sifat kemasan 
sintetis (Wittaya, 2013). Salah satu karakteristik yang perlu diperbaiki adalah daya serap air/WVTR (Water Vapor Transmission Rate).

Pembuatan edible film dari pektin yang berasal dari sumber lain selain kulit pisang telah banyak dilakukan. Penelitian pembuatan edible film berbahan dasar pektin albedo semangka menghasilkan produk dengan karakteristik terbaik yaitu ketebalan 0,145 mm; kuat tarik 366,4 $\mathrm{Kg}_{\mathrm{f}} / \mathrm{cm}^{2}$; elongasi $35,4 \%$; dan WVTR (Water Vapor Transmission Rate) 95,3 $\mathrm{g} / \mathrm{m}^{2}$.hari (Yulistiani dkk., 2019). Penelitian pembuatan edible film dari pektin kulit pepaya menghasilkan produk dengan karakteristik terbaik yaitu ketebalan 0,023 mm; kuat tarik 193,746 $\mathrm{Kg}_{\mathrm{f}} / \mathrm{cm}^{2}$; elongasi $14,223 \%$; dan WVTR $116.963 \mathrm{~g} / \mathrm{m}^{2}$.hari (Rosida dkk., 2018). Karakteristik elongasi dan WVTR dari kedua penelitian tersebut belum memenuhi standar edible film berdasarkan JIS Z 1707, 1975.

Pembuatan edible film yang berasal dari pektin kulit pisang belum banyak dilakukan. Penelitian pembuatan edible film dari pektin kulit pisang dengan pemlastis gliserol yang telah dilakukan menghasilkan produk dengan nilai karakteristik ketebalan film 0,0466 mm; kuat tarik 92,39 $\mathrm{Kg}_{\mathrm{f}} / \mathrm{cm}^{2}$; dan elongasi 16,67\% (Rofikah dkk., 2014). Penelitian pembuatan edible film dari pektin kulit pisang dengan penambahan pemlastis sorbitol $1 \%(\mathrm{v} / \mathrm{v})$ menghasilkan produk dengan karakteristik terbaik ketebalan film $0,125 \mathrm{~mm}$; kuat tarik $64,15 \mathrm{Kg}_{\mathrm{f}} / \mathrm{cm}^{2}$; elongasi 8,974\%; dan WVTR 6,523 $\mathrm{g} / \mathrm{m}^{2}$.hari (Andriasty dkk., 2015).

Karakteristik edible film dari pektin kulit pisang yang dihasilkan oleh penelitian sebelumnya belum memenuhi standar karakteristik edible film (Japanese Industrial Standard of Edible film, 1975). Secara khusus belum ada penelitian yang membandingkan pengaruh jenis dan konsentrasi pemlastis terhadap karakteristik pembuatan edible film dari pektin kulit pisang. Pada penelitian ini dilakukan studi literatur mengenai pengaruh jenis dan konsentrasi pemlastis (gliserol dan sorbitol) terhadap karakteristik daya serap air (WVTR) edible film dari pektin kulit pisang.

\section{METODE}

Studi literatur mengenai edible film dari pektin kulit pisang dengan variasi jenis dan konsentrasi pemlastis dilakukan dengan pengambilan data sekunder. Studi literatur diawali dengan mengidentifikasi masalah dari topik yang dibahas dan mengumpulkan sumber yang relevan. Literatur yang sudah terkumpul kemudian dirangkum dan dianalisis hingga menemukan hasil analisis dari masalah yang sedang dibahas. Setelah hasil analisis dijabarkan kemudian dibuat kesimpulan.

\section{HASIL DAN PEMBAHASAN}

Pembuatan edible film yang berbahan dasar hidrokoloid seperti pektin umumnya memiliki kelemahan yaitu sering rapuh dan tidak efisien sebagai penahan uap air karena bersifat hidrofilik (Wittaya, 2013). Untuk mengurangi sifat rapuh dari film biasanya ditambahkan bahan pengikat seperti pemlastis. Literatur yang akan dikaji terkait dengan pengaruh jenis pemlastis terhadap karakteristik edible film ditunjukkan dalam Tabel 1. 
Tabel 1. Perbandingan Hasil Karakteristik Edible film dengan Variasi Jenis Pemlastis

\begin{tabular}{ccccc}
\hline Penelitian & (Andriasty & (Nugroho & (Akili dkk., & (Salsabila \\
& dkk., 2015) & dkk., 2013) & 2012) & dkk., 2017) \\
\hline Pemlastis (v/v) & Sorbitol 1\% & Gliserol 1,8\% & Gliserol & Sorbitol \\
& & & $10 \%$ & $10 \%$ \\
WVTR & 8,62 & 2,530 & 3,934 & 3,66 \\
(g. $\mathrm{H}_{2} \mathrm{O} /$ jam.m ${ }^{2}$ ) & & & & \\
\hline
\end{tabular}

Edible film yang dibuat dengan penambahan pemlastis sorbitol menghasilkan nilai WVTR sebesar 8,62 g. $\mathrm{H}_{2} \mathrm{O} / \mathrm{jam} . \mathrm{m}^{2}$, sedangkan edible film yang dibuat dengan penambahan gliserol memiliki nilai WVTR sebesar 2,53 g. $\mathrm{H}_{2} \mathrm{O} / \mathrm{jam} . \mathrm{m}^{2} \quad$ (Tabel 1). Gliserol memiliki ukuran molekul yang lebih kecil dibandingkan dengan sorbitol, sehingga semakin banyak molekul yang dapat masuk kedalam jaringan amorphous film dan memperlambat transfer air dalam film (Wirawan dkk., 2012). Oleh karena itu, pemlastis gliserol dapat menahan laju uap air lebih efisien dibandingkan pemlastis sorbitol.

Pada produk edible film yang dibuat menggunakan jenis pemlastis yang berbeda namun memiliki konsentrasi yang sama yaitu 10\% (Tabel 1), pemlastis sorbitol menghasilkan nilai WVTR yang lebih rendah dibandingkan dengan pemlastis gliserol (Gambar 1). Pemlastis gliserol lebih hidrofilik dibandingkan sorbitol dan memiliki kemampuan plastisisasi yang besar (Anderson \& Simsek, 2019). Pemlastis gliserol juga memiliki berat molekul yang lebih rendah dibandingkan dengan sorbitol, maka pada pemlastis gliserol akan lebih banyak molekul yang terdifusi ke dalam matriks edible film dan dapat meningkatkan jarak intermolekuler sehingga ikatan hidrogen internal dan tegangan antar molekul pada edible film menurun. Kondisi tersebut akan memberikan ruang antar molekul semakin besar yang menyebabkan uap air dapat lewat dan permeabilitas meningkat.

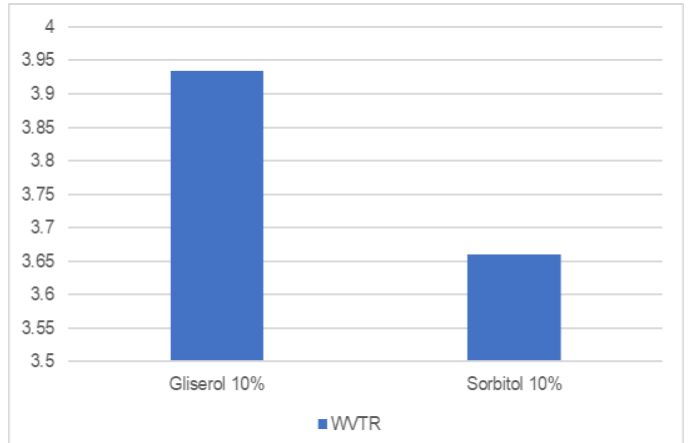

Gambar 1. Pengaruh jenis pemlastis terhadap WVTR

Untuk membandingkan pengaruh konsentrasi pemlastis terhadap karakteristik edible film yang dihasilkan, hasil penelitian yang akan dikaji diberikan dalam Tabel 2. Berdasarkan data dalam tabel tersebut, dibuat persamaan yang dapat digunakan untuk menunjukkan hubungan konsentrasi pemlastis dengan nilai WVTR sebagaimana ditunjukkan dalam Gambar 2.

Tabel 2. Pengaruh Konsentrasi Pemlastis Terhadap WVTR

\begin{tabular}{|c|c|c|c|}
\hline $\begin{array}{l}\text { Konsentrasi } \\
\text { Pemlastis } \\
\text { (Gliserol) }^{1}\end{array}$ & $\begin{array}{c}\text { WVTR } \\
\left(\text { g.H } \mathbf{H}_{2} \mathrm{O} /\right. \\
\text { jam.m } \\
\text { jam }^{1}\end{array}$ & $\begin{array}{c}\text { Konsentrasi } \\
\text { Pemlastis } \\
\text { (Sorbitol) }^{2}\end{array}$ & $\begin{array}{c}\text { WVTR } \\
\left(\mathrm{g} . \mathrm{H}_{2} \mathrm{O} /\right. \\
\text { jam.m } \\
\text { jam }^{2}\end{array}$ \\
\hline $0 \%$ & 6,236 & $5 \%$ & 3,94 \\
\hline $10 \%$ & 3,934 & $10 \%$ & 3,66 \\
\hline $20 \%$ & 5,368 & $15 \%$ & 4,66 \\
\hline $30 \%$ & 8,252 & & \\
\hline
\end{tabular}

${ }^{1}$ (Akili dkk., 2012)

${ }^{2}$ (Salsabila dkk., 2017) 


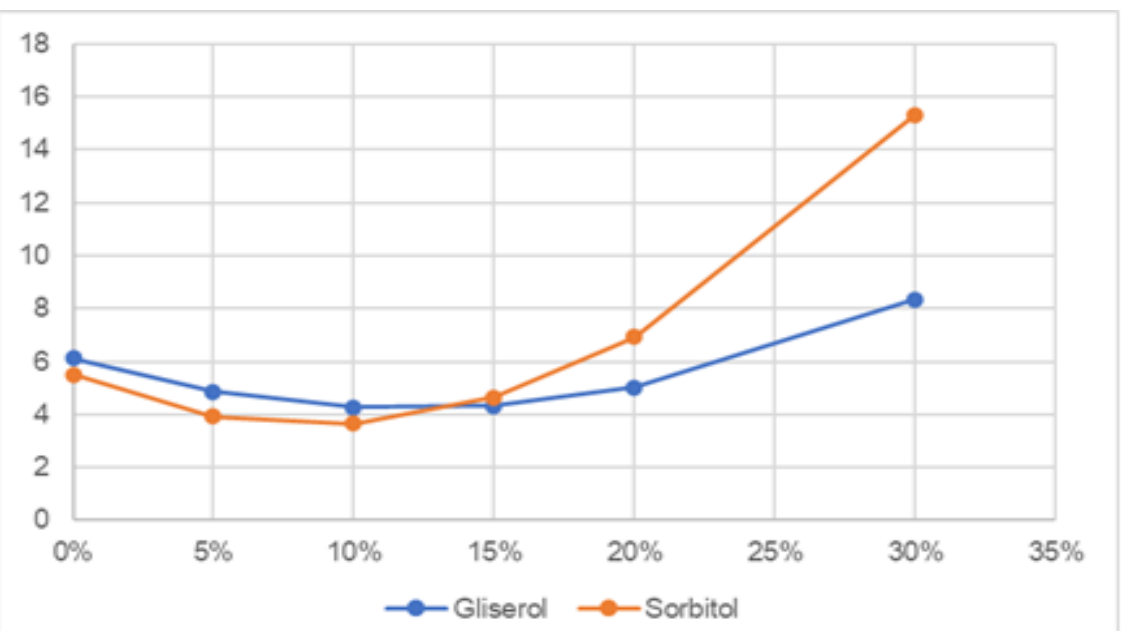

Gambar 2. Pengaruh konsentrasi pemlastis terhadap karakteristik WVTR edible film

Penambahan gliserol ke dalam edible film pada rentang konsentrasi 0 $15 \%$ dapat menurunkan nilai WVTR (Gambar 2), namun ketika konsentrasi gliserol ditambah, nilai WVTR meningkat. Edible film tanpa penambahan pemlastis memiliki nilai WVTR sebesar 6,236 g $\mathrm{H}_{2} \mathrm{O} / \mathrm{jam} . \mathrm{m}^{2}$ (Akili dkk., 2012) sedangkan dengan penambahan pemlastis nilai WVTR menurun. Hal ini disebabkan karena gliserol bersifat hidrofilik sehingga dapat meningkatkan jumlah air yang terikat yang membuat laju transmisi uap air meningkat karena jumlah gliserol dalam edible film meningkat. Selain itu, karena jarak intramolekul bertambah akibat penambahan pemlastis menyebabkan terciptanya ruang antarmolekul sehingga uap air lebih mudah melewati edible film. Nilai WVTR yang tinggi berarti edible film memiliki permeabilitas terhadap air yang tinggi.

Pada penambahan konsentrasi sorbitol, khususnya setelah konsentrasi $15 \%$, laju transmisi uap air pada edible film juga meningkat. Konsentrasi pemlastis pada permukaan edible film akan mengontrol penyerapan cairan atau padatan. Oleh karena itu, semakin banyak konsentrasi pemlastis dalam edible film menyebabkan peningkatan laju migrasi uap air pada edible film. Dari kedua jenis pemlastis tersebut, konsentrasi yang memberikan nilai WVTR terendah ada pada rentang 5-15\%.

\section{SIMPULAN}

Berdasarkan hasil studi literatur dapat disimpulkan bahwa pada produk edible film yang dibuat menggunakan pemlastis dengan konsentrasi 10\%, pemlastis sorbitol menghasilkan WVTR yang lebih rendah $\left(3,66\right.$ g. $\left.\mathrm{H}_{2} \mathrm{O} / \mathrm{jam} . \mathrm{m}^{2}\right)$ dibandingkan dengan pemlastis gliserol (3,93 g. $\left.\mathrm{H}_{2} \mathrm{O} / \mathrm{jam} . \mathrm{m}^{2}\right)$. Dari kedua jenis pemlastis tersebut, konsentrasi yang memberikan nilai WVTR terendah $(3,66-$ 4,66 g. $\mathrm{H}_{2} \mathrm{O} / \mathrm{jam} . \mathrm{m}^{2}$ ) ada pada rentang 5$15 \%$. Dari seluruh hasil penelitian yang dikaji, karakteristik WVTR produk edible film sudah memenuhi Japanese Industrial Standard (JIS Z 1707, 1975).

\section{UCAPAN TERIMA KASIH}

Terimakasih kepada Politeknik Bandung yang telah membiayai pelaksanaan penelitian skema penelitian mandiri (Nomor Kontrak: B/249.131/ PL1.R7/PG.00.03/2020) sehingga artikel ini dapat dihasilkan. 


\section{DAFTAR RUJUKAN}

Akili, M., Ahmad, U., \& Suyatma, N. (2012). Karakteristik Edible Film dari Pektin Hasil Ekstraksi Kulit Pisang. Jurnal Keteknikan Pertanian, 26(1).

Anderson, C., \& Simsek, S. (2019). How do arabinoxylan films interact withwater and soil? Foods, 8(6).

Andriasty, V., Praseptiangga, D., \& Utami, R. (2015). Pembuatan Edible Film Dari Pektik Kulit Pisang Raja Bulu (Musa Sapientum var Paradica baker) Dengan Penambahan Minyak Atsiri Jahe Emprit (Zingebir officinalle var. amarum) Dan Aplikasinya Pada Tomat Cherry (Lycopersiconesculentum var. cerasiforme). Jurnal Teknosains Pangan, 4(4), 1-7.

Nugroho, A., Basito, \& Katri, R. B. A. (2013). Kajian pembuatan edible film tapioka dengan pengaruh penambahan pektin beberapa jenis kulit pisang terhadap karakteristik fisik dan mekanik. Jurnal Teknosains Pangan Januari Jurusan Teknologi Hasil Pertanian Universitas Sebelas Maret Jurnal Teknosains Pangan.

Rofikah, Pratjojo, W., \& Sumarni, W. (2014). Pemanfaatan Pektin Kulit Pisang Kepok (Musa paradisiaca Linn) untuk Pembuatan Edible Film. IJCS - Indonesia Journal of Chemical Science, 3(1), 17-21.

Rosida, Sudaryati, \& Yahya, A. M. (2018). Edible Film from the Pectin of Papaya Skin (The Study of Cassava Starch and Glycerol Addition). Journal of Physics: Conference Series.

Salsabila, A., Revilia, W. T., Anwar, M. H., \& Education, B. (2017). Characteristics of Thickness and Permeability of Water Vapour on Edible Film Made From Banana
Peels Kepok Pectin With the Addition of Sorbitol. 4(Icons), 286-291.

Wirawan, S. K., Prasetya, A., \& Ernie, E. (2012). Pengaruh Plasticizer pada Karakteristik Edible Film dari Pektin. REAKTOR, 14(1).

Wittaya, T. (2013). Influence of Type and Concentration of Plasticizers on the Properties of Edible Film From Mung Bean Proteins. KMITL Science and Technology Journal.

Yulistiani, F., Kurnia, D. R. D., Agustina, M., \& Istiqlaliyah, Y. (2019). Pembuatan Edible Film Antibakteri berbahan dasar Pektin Albedo Semangka, Sagu, dan Ekstrak Bawang Putih. Fluida, 12(1), 29-34. 